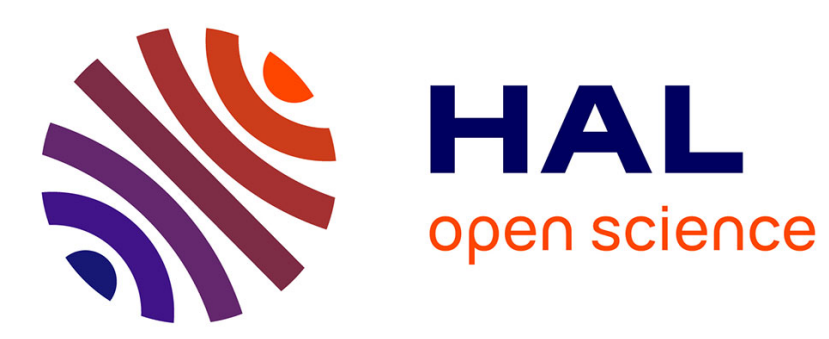

\title{
Detection of low temperature sensitization of alloy 800 with STEM Philips EM 430
}

\author{
V. Cíhal, G. Majo
}

\section{To cite this version:}

V. Cíhal, G. Majo. Detection of low temperature sensitization of alloy 800 with STEM Philips EM 430. Journal de Physique IV Proceedings, 1993, 03 (C7), pp.C7-89-C7-92. 10.1051/jp4:1993710 . jpa-00251716

\section{HAL Id: jpa-00251716 https://hal.science/jpa-00251716}

Submitted on 1 Jan 1993

HAL is a multi-disciplinary open access archive for the deposit and dissemination of scientific research documents, whether they are published or not. The documents may come from teaching and research institutions in France or abroad, or from public or private research centers.
L'archive ouverte pluridisciplinaire HAL, est destinée au dépôt et à la diffusion de documents scientifiques de niveau recherche, publiés ou non, émanant des établissements d'enseignement et de recherche français ou étrangers, des laboratoires publics ou privés. 


\title{
Detection of low temperature sensitization of alloy 800 with STEM Philips EM 430
}

\author{
V.J. ČÍHAL, V. ČÍHAL and G.D. MAJO* \\ University of Mining, Faculty of Metallurgy and Materials Engineering, 70833 Ostrava, $\check{C} R$ \\ * Electricité de France, Les Renardières, Ecuelles, France
}

\begin{abstract}
Introduction
The constitution and properties of the Cr21Ni33TiAl steel(alloy 800) imply that this steel has a good creep, heat and corrosion resistance, especially the stress corrosion resistance, but susceptibility to iniergranular corrosion is of interest due to the high nickel content. It is especially for the stainless variant of this steel with a low carbon content, alloyed with titanium and aluminium for the attainment of satisfactory technological and mechanical properties, that controversial data exist where stabilisation and resistance to intergranular corrosion are contemplated.

Resistance to stress corrosion in chlorides under a variety of conditions only slightly depends on carbon content and differences in chemical composition in heat-treated Cr21Ni33TiAl steel. Compared with the 08Cr18Nil0Ti steel and other austenitic molybdenummodified grades, its resistance in $35 \% \mathrm{MgCl}_{2}$ at $120^{\circ} \mathrm{C}$ is substantially higher. In the Round Robin Test with dilute $\mathrm{NaCl}$ solution at $200^{\circ} \mathrm{C}$ the steels under study have resistance superior to that of the austenitic-ferritic grades $02 \mathrm{Cr} 22 \mathrm{Ni} 5 \mathrm{Mo} 3 \mathrm{~N}$, and are closer to Inconel 600, NICRAL gr CrlBMo2 7 grade. The slow strain rate test in $35 \% \mathrm{MgCi}_{2}$ at $120^{\circ} \mathrm{C}$ and $10^{-7} \mathrm{~s}^{-1}$ revealed that their resistance index was very high.

Intergranular stress corrosion cracking

Evaporation from dilute $\mathrm{NaCl}$ solution and the slow-strain rate test in $\mathrm{MgCl}$, reveal the deleterious effects of low-temperature sensitising of gräin boundaries to intergranular corrosion, as has been documented by testing at $450^{\circ} \mathrm{C}$ for $30,000 \mathrm{~h}$; this sensitisation causes the susceptibility to intergranular stress corrosion cracking. Heat treatment lasting $30,000 \mathrm{~h}$ at $650^{\circ} \mathrm{C}$, which will eliminate the susceptibility of grain boundaries to intergranular corrosion, does not impair resistance to stress corrosion cracking.

The testing of resistance to intergranular corrosion in various environments, and the valiated zones in which a steel in susceptibile to intergranular corrosion depending on time and temperature of sensitising, show that during normal fabrication processes, such as welding, resistance to intergranular corrosion can be achieved in steel with composition Cr21Ni33TiAl especially by means of reducing the carbon content and solution treatment, or by stabilisation or stepped-down heat treatments at
\end{abstract}


lower temperature. Heat treatment can only little contribute to the bonding of carbon and titanium. However, this association can be promoted by previous cold forming, or hot forming at lower, temperatures. Resistance to intergranular corrosion after a long low-temperature sensitising is not reliably guaranteed either by reduced carbon content or higher degree of stabilisation. Low-carbon steels have a limited resistance to intergranular corrosion after some time at the critical temperature range.

Microanalysis of grain boundaries

Precipitation of chromium-rich carbides at grain boundaries within the critical temperature range undoubtedly caused considerable depletion in chromium in zone adjacent to the grain boundaries in stainless alloys, and the consequent susceptibility of the sensitised materials to intergranular corrosion and intergranular stress corrosion cracking /1/. Quantitative examination of the depletion in chromium was carried out on thin foils of Cr2INi33TiAl steels using the scanning TEM Philips EM 430 at $300 \mathrm{kV}$; the diameter of the spot being analysed was in range $10-20 \mathrm{~nm} / 2 /$. Materials Nos. $l$ and 2 , heat affected at 450 and $650^{\circ} \mathrm{C} / 30,000 \mathrm{~h}$, were studied (Table i).

Table 1. Chemical analysis of materials tested,wt.\%

\begin{tabular}{cllllllllll}
\hline $\begin{array}{c}\text { Mate- } \\
\text { rial } \\
\text { Nr. }\end{array}$ & $C$ & Mn & Si & $P$ & 5 & Cr & $N i$ & Ti & AI & $N$ \\
\hline
\end{tabular}

\begin{tabular}{lllllllllll}
1 & 0.053 & 1.180 & 0.570 & 0.022 & 0.005 & 20.70 & 33.71 & 0.440 & 0.290 & 0.018 \\
\hline 2 & 0.070 & 1.261 & 0.542 & 0.022 & 0.007 & 20.90 & 31.38 & 0.382 & 0.275 & 0.020 \\
\hline
\end{tabular}

In specimens heat-treated at $450^{\circ} \mathrm{C} / 30,000 \mathrm{~h}$, chromium carbides were very dense at grain boundaries, and this was accompanied by a significant depletion in chromium and enrichment of zones adjacent to the grain boundaries with nickel. Chromium and nickel concentrations at the grain boundaries were approximately 10.5 and $39.7 \mathrm{wt} . \%$, respectively, see figs. la, and $1 \mathrm{~b}$. The widths of the concentration profiles were, respectively, approximately 500-600 nm and $300 \mathrm{~nm}$ for chromium and nickel.

Depletion in chromium at the grain boundaries is roughly balanced after heat treatment at $650^{\circ} \mathrm{C} / 30,000 \mathrm{~h}$; the difference in chromium contents in the matrix and at the grain boundaries is approximately $1 \%$, see Fig.la.

The width available for the depletion in chromium to occur is much greater than that for the enrichment with nickel, in specimens with severely depleted grain boundaries; this implies that, in the austenite, chromium diffuses much faster than nickel, and the mass conservation law must be satisfied through the flow of iron atoms.

Referring to the time-temperature dependencies of sensitising of stainless steels, it can be assumed that as times extend and temperatures increase during the heat treatments, chromium contents will rise and nickel contents drop, at the grain boundaries. The tangents of the concentration profiles at the grain boundary plane have a very high gradient $\left(\delta_{c} / \delta_{d} \gg 0\right)$ at very short heat treat- 
ment times, and this state corresponds to the precipitation of carbides and the chromium depletion at the grain boundaries. The precipitation decelerates as the gradient of line decreases, and at $\left(\delta_{C}^{\prime}\left(\delta_{d}\right)_{d=0}=0\right.$ the precipitation stops and equalisation of chromiuñ prevails at the grain boundaries.

Taking the profile for material 1 , it can be assumed that carbide precipitation has been terminated. Considering the relatively increased minimum level of chromium content, of $10.5 \%$, chromium-atom flow towards the grain boundary must have taken place before the end of the carbide precipitation, as is documented by models describing the depletion in chromium $/ 3 /$.

Considering the 12.5 wt.\% of chromium to be the limit value for a stainless steel,'s ability to passivate, then the corresponding width of the depletion of grain boundaries in chromium will be, for material No. 1, one order of magnitude greater than the critical width at which sensitising is initiated in Cr2lNi33TiAl steel. The chromium concentration profiles confirm the theories concerning the temperature and time dependencies that the stainless steels obey when being sensitised to intergranular corrosion. It is generally assumed in the models describing the chromium depletion of grain boundaries associated with the precipitation and growth of $\mathrm{M}_{23} \mathrm{C}_{6}$ and/or $M_{7} C_{3}$ carbides in stainless steels or nickel alloys $/ 3,4 /$, that a continuous film of these carbides is formed at the grain boundaries. However, this simplification is not in agreement with either the morphology and distribution of carbides at the grain boundaries or with the chromium and nickel concentration profiles across the grain boundary even though the grain boundaries have become extremely depleted in carbides. Simplified, globular carbide particles during the initial stages of precipitation should rather be considered in thermodynamic and kinetic assumptions because only a limited zone of considerable depletion in chromium in the vicinity of these particles must be expected due to the differences, in orders of magnitude, of the chromium diffusion along the grain boundaries and in the matrix.

During advanced stages, when the concentration change profile extends, the continuity of the network of individual carbides that occupy the grain boundaries, improves; carbide formation is complete at this stage and chromium content at the grain boundaries becomes gradually equalised through volume diffusion from the matrix. However, not even does this continuous carbide network appear to be a continuous carbidic phase, considering the profile obtained by microanalysis. The concentration profile for chromium content and the corresponding tangents imply that, with the gradient of line $\left(\delta_{c} / \delta_{d}\right) d=0=0$, the precipitation has ended and processes conducive to the dajulisation of chromium and nickel contents, have become predominant.

Low-temperature sensitisation at which reduction of chromium content to $10.5 \%$ was documented by TEM, manifested itself through a reduction of the values of depassivation and repassivation potentials, which is a sign that resistance to pitting in chlorides is impaired, compared with these steel types after solution treatment. 


\section{Conclusion}

Stress corrosion tests in chlorides-containing environments showed that this steel, had a very high resistance to stress corrosion cracking when subjected to solution treatment; this resistance was proportional to the nickel content in the steel.

Sensitised within the critical temperature range, this steel becomes more susceptible to stress corrosion cracking, and this cracking becomes intergranular during the later stages; this fact makes it

necessary to study the processes taking place at the grain boundaries and to ensure resistance to intergranular corrosion in practice.

Sensitised within the critical temperature range, it loses something of its resistance to pitting in chlorides.

\section{References}

/1/ ČIHAL V., Intergranular Corrosion of Steels and Alloys, ELSEVIER-SNTL, Amsterdam-Praha(1984).

/2/ VAN DUYSEN J., GUTTMANN M., Proc.Int.Colloq.on Stainless Steels with Particular Focus on Corrosion with or without Mechanical Stress, Faculté Polytechnique de Mons, Belgique(1988), 91.

13/ STAWSTRÖM C., HILLERT M., J.Iron SteeI Inst. 207, 1969,77. /4/ WAS G.S., KRUGER R.M., Acta Met., 33, 1985, 841.

Fig. 1 Concentration profiles of $\mathrm{Cr}$ a) and $\mathrm{Ni}$ b) in wt.\% on both sides away from grain boundary in material $1\left(450^{\circ} \mathrm{C} / 30,000 \mathrm{~h}\right)$ and $2\left(650^{\circ} \mathrm{C} / 30,000 \mathrm{~h}\right)$ - curves a and -...-, respectively.
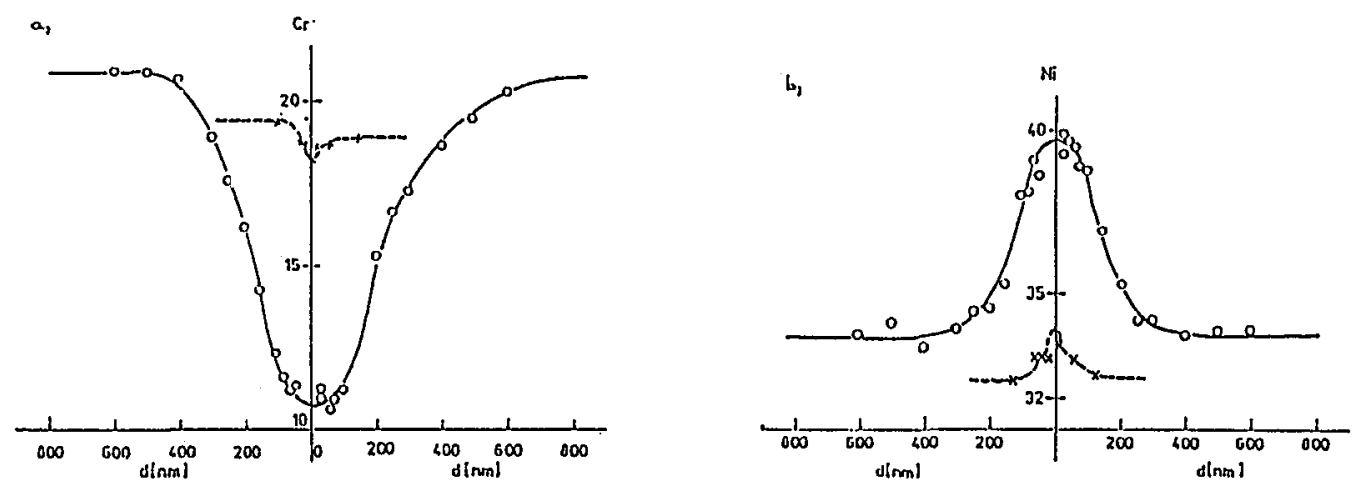